\title{
CONTROLLING AMMONIA LOSSES DURING MANURE COMPOSTING WITH THE ADDITION OF PHOSPHOGYPSUM AND SIMPLE SUPERPHOSPHATE
}

\author{
L.I. PROCHNOW; J.C. KIEHL; F.S. PISMEL; J.E. CORRENTE ${ }^{3}$ \\ 1 Depto. de Ciêncıa do Solo-ESALQ/USP, C.P. 9, CEP: 13.418-900 - Piracicaba, SP. \\ ${ }^{2}$ Estagiário, Depto. de Ciência do Solo - ESALQNSPP. \\ ${ }^{3}$ Depto. de Matemática e Estatistica - ESALQUSP, C.P. 9, CEP: 13.418 .900 - Piracicaba, SP.
}

\begin{abstract}
With the purpose of evaluating the effectiveness of phosphogypsum and simple superphosphate in controlling ammonia losses by volatilization during the process of manure composting, an experiment was carried out in closed flasks of 1.6 liter, in which different rates $\left(50,100,150\right.$ and 200 kg.t $\left.{ }^{\prime}\right)$ of phosphogypsum and simple superphosphate were mixed with a substrate composed of equal amounts (on weight basis) of fresh chicken manure and cattle manure. Ammonia lost by volatilization was determined after 7,14,21,28 and 35 days by trapping the gas in sulfuric acid solution placed in a small glass vial which, in turn, was maintained inside the volatilization nask The remaining acid after the exposure to ammonia was determined by titration with $0.025 \mathrm{~N} \mathrm{NaOH}$. The amount of ammonia lost by volatilization from the samples decreased with the addition of both products, but for all rates applied, phosphogypsum was more efficient than simple superphosphate. The reduction in volatilization increased with the rate of application of both additives. There was an evidence that the reduction of ammonia loss was due to the presence of gypsum in the additives. KEY WORDS: ammonia losses, phosphogypsum, simple superphosphate, manure composting.
\end{abstract}

\section{CONTROLE DAS PERDAS DE AMÔNIA DURANTE A COMPOSTAGEM DE ESTERCOS COM ADIÇÃO DE FOSFOGESSO E SUPERFOSFATO SIMPLES}

RESUMO: Com o propósito de avaliar a eficiência do gesso agrícola e do superfosfato simples em controlar as perdas de amônia por volatilizaçāo durante o processo de compostagem de estercos, foi conduzido um experimento em frascos de vid ro fechados de 1,6 litro de capacidade, nos quais diferentes quantidades $\left(50,100,150\right.$ e $\left.200 \mathrm{~kg} \cdot \mathrm{t}^{-1}\right)$ daqueles materiais foram misturadas com um substrato composto de uma mistura de partes iguais (em massa) de estercos frescos de galinha e de bovino. A amônia perdida por volatilizaçăo foi determinada após 7, 14, 21, 28 e 35 dias, coletando-se o gás em soluçāo de ácido sulfúrico encerrada em pequeno recipiente o qual era, por sua vez, colocado no interior do frasco. $O$ ácido remanescente após o periodo de exposição à amônia era determinado por titulação com solução de $\mathrm{NaOH} 0,025 \mathrm{~N}$. A quantidade de amônia perdida do esterco por volatilizaçăo diminuiu com a adiçăo de ambos os materiais estudados, mas para todas as doses aplicadas o gesso agrícola fol mais eficiente do que o superfosfato simples. Os decréscimos da volatilização foram tanto maiores quanto mais elevadas eram as doses de ambos os aditivos. Houve evidências de que a redução das perdas de amônia deveu-se à presença do gesso nos materiais estudados.

DESCRITORES: perdas de amônia, gesso agricola, suerfosfato simples, compostagem de estercos.

\section{INTRODUCTION}

A very common problem during manure composting is the liberation to the atmosphere of certain amount of nitrogen in the form of ammonia gas $\left(\mathrm{NH}_{3}\right)$. The process is the result of the activity of microorganisms on the organic nitrogen compounds of the manure, which are converted to $\mathrm{NH}_{3}$. Two consequences of this loss are the decrease of the amount of available nitrogen in the composted material and the increase of air pollution (GALBALLY \& ROY, 1983; MOLLER \& SCHIEFERDECKER, 1985).
According to ALEXANDER (1977), ammonia volatilization is almost certain to occur when the concentration of nitrogen in the organic material is higher than $2.4 \%$ because any amount exceeding that necessary for the microorganisms to decompose the organic material will be discarded as $\mathrm{NH}_{3}$. Losses of ammonia as high as $50 \%$ have been reported for $\mathrm{NH}_{4}{ }^{+}$-forming fertilizers and animal manure applied on the soil surface (TERMAN, 1979).

Phosphogypsum and ordinary superphosphate have been recommended to reduce ammonia losses during the composting of organic 
materials, specially manure (COLLINGS, 1955). In Brazil, MALAVOLTA (1967) indicates the addition of $50 \mathrm{~kg}$ of any of these products to each metric ton of manure. Later, the same author (MALAVOLTA, 1979) reduces the recommended amount to $25 \mathrm{~kg}$ per metric ton. TIBAU (1983) recommends the rate of $12.5 \mathrm{~kg} . \mathrm{t}^{-1}$, and also emphasizes the effects of both, gypsum and simple superphosphate, in decreasing $\mathrm{NH}_{3}$ volatilization from manure piles. According to KIEHL (1985), gypsum may be scattered on the stable floor in amounts of 1.0 to 1.5 $\mathrm{kg}$ per equine animal, 1.0 to $2.0 \mathrm{~kg}$ per bovine, 0.5 $\mathrm{kg}$ per sheep or swine and 100 to $200 \mathrm{~g}$ per chicken. Reductions from $56 \%$ to $3 \%$ in losses of $\mathrm{NH}_{3}$ were achieved by TRANI (1981) with the addition of an average of $30 \mathrm{~kg} . \mathrm{t}^{-1}$ of simple superphosphate.

GLÓRIA et al. (1991) compared the effect of adding simple superphosphate (powdered or granulated), phosphogypsum, partially acidulated rock phosphate and ground rock phosphate to chicken manure on ammonia losses and found that powdered simple superphosphate, followed by phosphogypsum, were effective in controlling the losses, but emphasized that the amounts of these products recommended by MALAVOLTA et al. (1979) and TRANI (1981) are too low to restrain ammonia volatilization.

In spite of these favorable results obtained with gypsum, other field and greenhouse experiments have demonstrated that this material is not effective in controlling ammonia losses from urea applied to soils (FENN et al., 1981; KIEHL, 1989).

It is clear from these results that the number of experiments carried out to study the effect of additives in controlling ammonia losses from manure is very low, and also that the information provided by these studies are contradictory. The purpose of this experiment was to evaluate the efficiency of phosphogypsum and simple superphosphate in controlling volatilization losses of ammonia during the process of manure composting. .

\section{MATERIALS AND METHODS}

The organic material used in this experiment was obtained by mixing equal amounts , in weight basis, of dried and ground fresh chicken manure ( $54.5 \mathrm{~g}^{\mathrm{kg}} \mathrm{kg}^{-1} \mathrm{~N}, \mathrm{C} / \mathrm{N}$ ratio= 6 ) and cattle manure (21.2 g.kg-1 $\mathrm{N}, \mathrm{C} / \mathrm{N}$ ratio $=19$ ). The mixture showed a concentration of $35.3 \mathrm{~g} \cdot \mathrm{kg}^{-1} \mathrm{~N}$ and a $\mathrm{C} / \mathrm{N}$ ratio of $1: 1$.

The experiment was carried out in a completely randomized factorial design with four replicates. The treatments consisted of two additives, phosphogypsum (a residue from the phosphoric acid production plants, containing $17.93 \%$ of S) and ground simple superphosphate (commercial fertilizer containing $19.31 \%$ of total $\mathrm{P}_{2} \mathrm{O}_{5}$ and $12.93 \%$ of $\mathrm{S}$ ), applied at the rates equivalent to $50,100,150$ and $200 \mathrm{~kg} . \mathrm{t}^{-1}$ of prepared substrate. A control treatment without additive was included. The mix of substrate and additive, containing $0.35 \mathrm{~g}$ of $\mathrm{N}$, was moistened to $150 \%$ of water and immediately transferred to a 1.6-liter glass flask. A small glass vial containing $10 \mathrm{ml}$ of $0.1 \mathrm{M}$ sulfuric acid and a few drops of metilorange indicator solution was placed inside each flask, above the substrate, to trap the volatilized ammonia. The indicator solution was added in order to monitor the neutralization of the acid and avoid reaching the saturation point. When necessary, the exposed acid solution was replaced by a fresh solution before the pre-defined period of time. The flasks were hermetically closed with plastic caps and left on the laboratory bench. After 7, 14, 21, 28 and 35 days the acid in the vial was replaced by fresh solution. The exposed acid solution was titrated with a $0.025 \mathrm{M}$ $\mathrm{NaOH}$ solution and the amount of volatilized ammonia calculated by the difference between the amount of acid placed in the trap and the amount remaining after exposition to $\mathrm{NH}_{3}$.

Total amounts of $\mathrm{NH}_{3}$ volatilized, calculated by the sum of the amounts collected each week, were subjected to analysis of variance. The effect of additive rates was studied by polynomial regression analysis.

\section{RESULTS AND DISCUSSION}

Significant amounts of $\mathrm{NH}_{3}$ were lost during the composting of manure (Figure 1). Most of the losses (about $73 \%$ ) occurred within the first two weeks, decreasing markedly in the following periods and showing a tendency for stabilization in the fifth week. JANZEN \& McGINN (1991) attribute the initial high losses of ammonia apparently to the ammonification of labile $\mathrm{N}$, followed by an undefined period of slow volatilization, probably from the mineralization of more recalcitrant $\mathrm{N}$ fractions. It also can be seen in Figure 1 that both additives reduced ammonia volatilization along the whole experiment.

The total amount of $\mathrm{N}-\mathrm{NH}_{3}$ volatilized during the period of 35 days from the manure sample not treated with the additives was $178.74 \mathrm{mg}$ (Table 1); this amount represents $51 \%$ of the total $\mathrm{N}$ content of the manure. The addition of $50 \mathrm{~kg} . \mathrm{t}^{-1}$ of phosphogypsum reduced ammonia loss to $111.19 \mathrm{mg}$ 


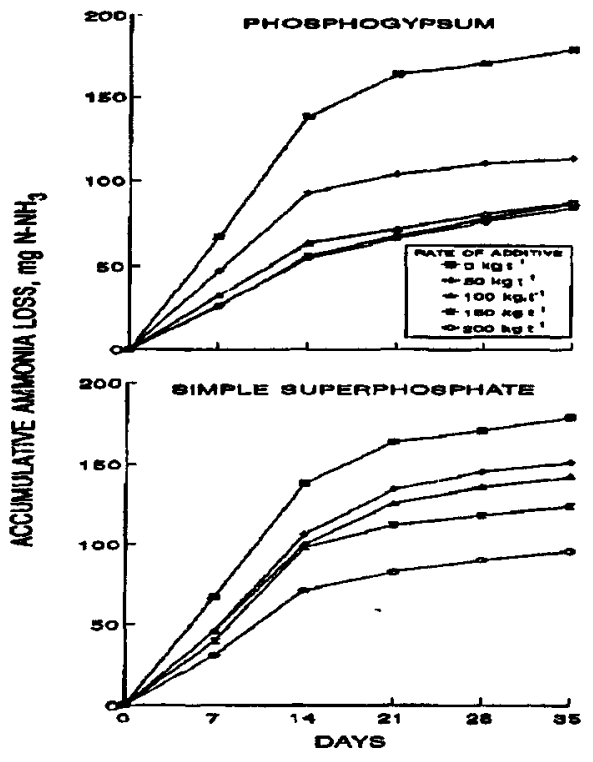

Figure 1. Accumulative losses of $\mathrm{N}-\mathrm{NH}_{3}$ from manure as influenced by the addition of different rates of phosphogypsum (PG) and simple superphosphate (SS).

$\mathrm{N}-\mathrm{NH}_{3}$ (reduction of $38 \%$ ), whereas higher rates gave losses of 84.30 to $87.23 \mathrm{mg} \mathrm{N}-\mathrm{NH}_{3}$ (reductions of $53 \%$ to $51 \%$ ). For simple superphosphate maximum reduction in volatilization occurred at the higher rate of $200 \mathrm{~kg} \cdot \mathrm{t}^{1}$, but even at this dose the amount of ammonia lost was higher than the observed with the addition of $100 \mathrm{~kg} . \mathrm{t}^{\mathrm{t}}$ of phosphogypsum.

For all applied rates phosphogypsum was superior to simple superphosphate in reducing the losses (Table 1). This observation does not confirm the results obtained by GLÓRIA et al. (199i), since these authors found that simple superphosphate was more effective than phosphogypsum in controlling ammonia volatilization.

The regression analysis showed significant effects of the applied rates of additives. In Figure 2 it can be seen that the amount of evoluted $\mathrm{NH}_{3}$ decreased as the doses of additive increased. This effect was linear for the simple superphosphate and quadratic for the phosphogypsum.

The fact that phosphogypsum was superior to simple superphosphate in controlling ammonia volatilization, and that simple superphosphate contains about $50 \%$ of gypsum, leads to the hypothesis that the gypsum or the sulfate in the simple superphosphate was the component responsible for decreasing $\mathrm{NH}_{3}$ evolution. To test this hypothesis, a regression analysis was performed relating the ammonia losses to the amount of gypsum applied to the manure as phosphogypsum or simple superphosphate, and a high and significant linear regression coefficient $(r=-0.85, P<0.01)$ was obtained; this indicates that the controlling mechanism of ammonia volatilization might be related to the presence of gypsum or sulfate in the composting manure. According to TEUSCHER \& ADLER (1965), gypsum reacts with the ammonium carbonate formed in the pile producing ammonium sulfate and calcium carbonate:

$$
\left(\mathrm{NH}_{4}\right)_{2} \mathrm{CO}_{3}+\mathrm{CaSO}_{4} \rightarrow\left(\mathrm{NH}_{4}\right)_{2} \mathrm{SO}_{4}+\mathrm{CaCO}_{3}
$$

The results obtained in this experiment confirms the observation of GLORIA et al. (1991) that the amounts of simple superphosphate or phosphogypsum usually recommended in the literature for controlling ammonia losses from manure piles have been underestimated. Malavolta, for example, advises rates of $50 \mathrm{~kg} \cdot \mathrm{t}^{-1}$ (MALAVOLTA, 1967) or half of this dose (MALAVOLTA, 1979), whereas TIBAU (1983) indicates only $12.5 \mathrm{~kg} . \mathrm{t}^{-1}$. According to the present research, a reasonable control of volatilization would require the application of at least $100 \mathrm{~kg}$ of phosphogypsum per ton of manure or a still higher amount of simple superphosphate; it is worth to say that this practice would introduce at least $10 \%$ of mineral constituents in the material, reducing the organic matter content of the final product.

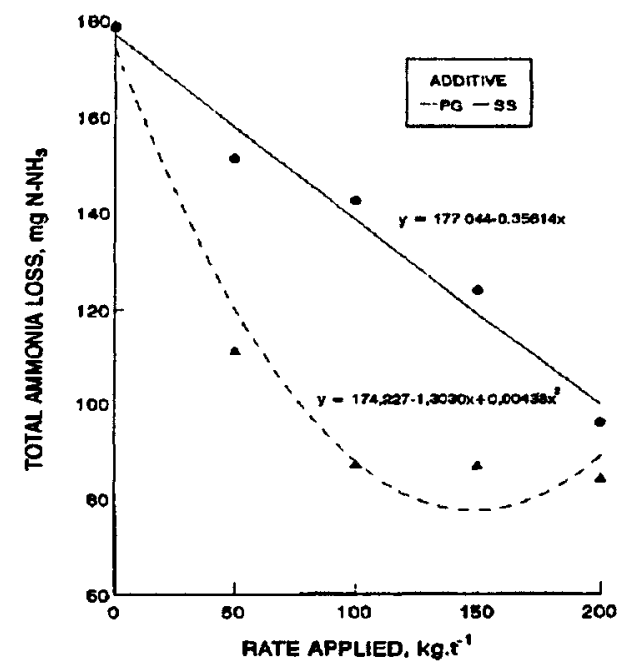

Figure 2. Total $\mathrm{N}-\mathrm{NH}_{3}$ loss from manure as influenced by the addition of different rates of phosphogypsum (PG) and simple superphosphate (SS) 
Tabela 1. Total amount of $\mathrm{N}_{-} \mathrm{NH}_{3}$ volatilized during 35 days, from a mixture of chicken and cattle manures treated with different rates os phosphogypsum (PG) and simple superphosphate (SS) ${ }^{(1)}$

\begin{tabular}{ccr}
\hline \hline Rate of PG or SS & PG & SS \\
\hline kg.t & & \\
& & \\
0 & $178.74 \mathrm{~A}$ & $178.74 \mathrm{~A}$ \\
50 & $111.19 \mathrm{~B}$ & $151.23 \mathrm{~A}$ \\
100 & $87.23 \mathrm{~B}$ & $142.38 \mathrm{~A}$ \\
150 & $86.98 \mathrm{~B}$ & $123.96 \mathrm{~A}$ \\
200 & $84.30 \mathrm{~B}$ & $95.84 \mathrm{~A}$ \\
Average & $109.69 \mathrm{~B}$ & $138.43 \mathrm{~A}$ \\
\hline \hline
\end{tabular}

(1) Figures with the same letter in the line are not significantly different by Tukey test at $P<0,01$. Coefficient of variation, $4(4.29 \%)$.

\section{CONCLUSIONS}

a) The amount of ammonia lost by volatilization from the manure decreased with the addition of both phosphogypsum and simple superphosphate, but for all rates applied, phosphogypsum was more efficient than simple superphosphate;

b) The reduction in volatilization increased with the rate of application of both additives;

c) There was an evidence that the reduction of ammonia loss was due to the presence of gypsum or sulfate in the studied additives.

\section{REFERENCES}

ALEXANDER, M. Introduction to soil microbiology. 2. ed. New York: John Wiley, 1977. 467p.

COLLINGS, G.H. Commercial fertilizers. 5.ed. New York: Mc Graw Hill Book, 1955. 617p.

FENN, L.B.; TAYLOR, R.M.; MATOCHA, J.E. Ammonia losses from surface applied nitrogen fertilizer as controlled by soluble calcium and magnesium: General theory. Soll Science Society of American Journal, madison, v. 45, p. $777-781,1981$.

GALBALLY, 1.E.; ROY,C.R. The fate of nitrogen compounds in the atmosphere. In: FRENEY, J.R; SIMPSON, J.R. (ed) Gaseous loss of nitrogen from plant-soll systems. Hague: Martinus Nijhoff, 1983. p.265-284.

GLÓRIA, N.A; BARRETTO, M.C.V. MORAES, C.J.; MATTIAZZO-PREZOTTO, M.E. Avaliação do gesso e de alguns fosfatos como inibidores da volatilizacaio de amônia de estercos. Revista Brastleíra de Chência do Solo, Campinas, v.15, n.3, p.297-301, 1991.

JANSEN, H.H..; McGINN, M. Volatile loss of nitrogen during decomposition of legume green manure. Soll Biology Biochemistry, Oxford, v.23,n.3, 291-297, 1991.
KIEHL, E.J. Fertilizantes orgânicos. São Paulo: Agronômica Ceres, 1985. 492p.

KIEHL, J.C. Emprego de sais inorgânicos no controle da volatilizaçăo de amônia decorrente da aplicação de uréia no solo. Piracicaba, 1989. 108p. Tese (LIVREDOCENNCIA) - Escola Superior de Agricultura Luiz de Queiroz, Universidade de São Paulo.

MALAVOLTA, E. Manual de química agricola: adubos e adubaçð̃o. 2. ed. São Paulo: Agronômica Ceres, 1967. $606 p$.

MALAVOLTA, E. ABC da adubaçăo. 4. ed. São Paulo: Agronômica Ceres, 1979. 256p.

MOLLER, D.; SCHIEFERDECKER, H. A relationship between agricultural $\mathrm{NH}_{3}$ emissions and the atmospheric $\mathrm{SO}_{2}$ content over industrial areas. Atmospheric Environment, Oxford, v.19, p.695-700, 1985.

TERMAN, G.L. Volatilization losses of nitrogen as ammonia from surface-applied fertilizers, organic amendments, and crop residues. Advances in Agronomy, New York, v.31, p.189-23, 1979.

TEUSCHER, H.; ADLER, R. El suelo $y$ su fertilidad. Mexico: Companhia Editorial Continental, 1965. S10p.

TIBAU, AO. Matéria orgânica e fertillidade do solo. 2 . ed. São Paulo: Nobel, 1983. 220p.

TRANI, P.E. Emprego de superfosfato simples com estenco. Campinas, CATI, 1981. 5p. (Instruçăo prática, 215).

Recebido para publicação em 09.01 .95

Aceito para publicação em 24.07.95 